\title{
Čuvaonice, radne prostorije i konzervatorsko-preparatorska služba od osnutka Etnografskoga muzeja do danas
}

- Tekst donosi prikaz izmjena izvršenih unutar Muzeja vezano za smještaj stalnoga postava i dogradnju čuvaonica i radnih prostorija od osnutka Muzeja 1919. godine do danas. Zgrada u kojoj je smješten Etnografski muzej jedna je od malobrojnih u gradu Zagrebu koja je građena s muzejskom namjenom, no njezina konstrukcija i koncept unutarnjega uređenja od samoga početka nisu bili adekvatni za obavljanje svih muzejskih djelatnosti, uslijed čega su u nekoliko navrata rađene prenamjene i dogradnje prostorija.

Ključne riječi: Etnografski muzej (Zagreb)

stalni postav, čuvaonice, konzervatorsko - preparatorska služba

\section{UVOD}

Zgrada Trgovačko-obrtnoga muzeja, u koju je osnutkom 1919. godine smješten Etnografski muzej, zbog svoje konstrukcije i koncepta unutarnjega uređenja nije bila adekvatna za djelovanje i razvitak Muzeja. ${ }^{1}$ Neadekvatnost prostora najviše se očitovala u nedostatku prostora za rad stručnoga i tehničkoga osoblja te u nedostatku prostora za pohranu muzejskoga fundusa, što je onemogućavalo širenje i suvremeno koncipiranje Muzeja. Takva situacija je dovela do nužnih izmjena i dogradnji koje su se izvršile u nekoliko navrata unutar sto godina postojanja Muzeja. Adaptacijom zgrade od 1968. do 1972.

1 Zgrada je građena 1902. - 1903. godine kao izložbeni prostor Trgovačko-obrtne komore. 
godine kojom su, među ostalim, osigurane i radne prostorije za osoblje zaduženo za zaštitu muzejskoga fundusa postupno se povećao broj, ali i stručna sprema djelatnika konzervatorsko-preparatorskoga odjela. U sto godina postojanja Muzeja, od osoblja zaduženoga za zaštitu tekstilne građe i djelatnika "vještih stolarskim radovima", došlo se do razine u kojoj se unutar Muzeja izvode najzahtjevniji konzervatorsko-restauratorski zahvati. Iako zgrada ne osigurava adekvatan prostor za pohranu fundusa ni stabilne mikroklimatske uvjete, kakvi su neophodni za opstojnost i održivost zbirki, sustavnim provođenjem mjera preventivne konzervacije i restauracije pokušava se neutralizirati negativan utjecaj neadekvatnih uvjeta u zgradi Muzeja.

\section{ČUVAONICE I RADNE PROSTORIJE ETNOGRAFSKOGA MUZEJA}

U prvim desetljećima nakon osnutka Muzeja u nekoliko navrata su rađene izmjene u stalnom postavu dok su radne prostorije i čuvaonice izmještene jednom. Tek su se prilikom adaptacije zgrade od 1968. do 1972. godine i dogradnjom petoga kata 1989. godine dobili adekvatni prostori za pohranu građe i smještaj stručnoga i tehničkoga osoblja. U nastavku teksta kronološki su navedene i opisane sve značajnije promjene koje su omogućile nesmetano djelovanje svih muzejskih službi.

\section{RAZDOBLJE OD 1919. DO 1968. GODINE}

Osnivanjem Etnografskoga muzeja u Zagrebu 1919. godine spojene su postojeće etnografske zbirke prikupljene u Narodnom muzeju sa zbirkom tekstila Salamona Bergera i smještene u zgradu Trgovačko-obrtnoga muzeja (Gjetvaj 1989: 17-19). Prvih godina nakon osnutka muzejski fundus brojao je oko 20000 predmeta, ${ }^{2}$ a uz inventiranje i katalošku obradu postojeće građe pristupilo se prikupljanju predmeta putem mreže prijatelja Muzeja ${ }^{3}$ i pripremi građe za izlaganje.

Prvi stalni postav otvoren je za javnost 19. lipnja 1922. godine. Postavljen je u lijevom krilu prizemnoga dijela zgrade i na prvom katu dok su radne prostorije zaposlenika bile smještene $\mathrm{u}$ desnom krilu prizemnoga dijela zgrade. Činile su ih:

"Soba stručnjaka za tekstil, radna soba muzejskog crtača, spremište fotografskih aparata, sanduka, manekena i dr., predio za čišćenje, dezinfekciju i restauriranje muzejskih predmeta, dio magazina, prijeklet upravnika i biblioteka, administracija i biblioteka, prijeklet za čuvara zbirke i biblioteka, soba za razvijanje fotografskih snimaka, stan vratarov, ormari povjerenstva za očuvanje narodnih starina.” (Ibid.: prilog 1)

2 Danas fundus broji oko 70000 predmeta.

3 "Da bi se posao oko prikupljanja predmeta lakše i brže obavio stvorena je mreža prijatelja Muzeja, koji su iz ljubavi prema tradicijskom narodnom blagu sakupljali predmete i poklanjali ih Muzeju. Na prijedlog uprave Muzeja Povjereništvo za prosvjetu i vjeru izdalo je Naredbu o osnivanju Službe povjerenika Etnografskog muzeja u Zagrebu" (Gjetvaj 1989: 20). 
Prve promjene u postavu izvršene su 1934. i 1935. godine ${ }^{4}$ prilikom kojih je napravljen i novi razmještaj osoblja Muzeja. Stalni postav je zauzimao desno krilo i dio prostora u lijevom krilu prizemlja zgrade te cijeli prvi kat dok su radne prostorije, koje su činile "Kancelarija upravnika, sekretarijat, crtač, stručno odjeljenje, stan vratarov, fotografska soba" (Ibid.: prilog 5) bile smještene u južnom uličnom dijelu lijevoga krila zgrade. Dio čuvaonica bio je smješten u podrum (za predmete od drva, keramike, tekstila i kože) dok je najveći dio tekstile građe bio pohranjen u ormarima koji su sa stolarskom radionicom bili smješteni u prostoriji uz dvorište lijevoga krila zgrade. U prostoru koji se nastavlja na stolarsku radionicu ${ }^{5}$ bili su pohranjeni ćilimi, vunena tkanja i zbirka nakita, unutar koje je bila smještena i radna prostorija preparatora (Gjetvaj 1973b: 20). Nedugo nakon tih izmjena, u razdoblju od 1939. do 1941., uređen je i podrum u južnom dijelu zgrade, u kojem se također čuvala građa. Početkom Drugoga svjetskog rata 1941. sva prvorazredna građa pohranjena je u specijalne sanduke i smještena u sklonište izvan muzejske zgrade, dok je ostala građa također pohranjena u sanduke i smještena u podrum. Nakon završetka rata započelo je uređivanje evakuiranoga materijala i priprema za ponovno izlaganje u stalnom postavu Muzeja (usp. Gjetvaj 1989: 24).

\section{RAZDOBLJE OD 1968. DO 1972. GODINE}

Nepovoljni uvjeti u kojima se odvijao rad u Muzeju zbog nedostatka prostora i dotrajalosti zgrade (Gjetvaj 1973b: 20-21) nametnuli su potrebu za adaptacijom zgrade koja je realizirana od 1968. do 1972. godine. Idejni projekt građevinske adaptacije zgrade volonterski je izradio arhitekt Aleksandar Freudenreich. Tom prilikom prenamijenjene su postojeće prostorije i dograđene su nove, čime su radne prostorije odvojene od izložbenih te su osigurani prostori za čuvaonice i preparatorske radionice.

Adaptacijom je dograđen četvrti kat na kojem je u desnom krilu zgrade smještena preparatorska radionica za tekstil. Uz radionicu je dograđen balkon s izlazom na terasu ravnoga krova (što je omogućilo sezonsko zračenje i čišćenje tekstila), dok je za prenošenje teških predmeta između balkona i krovne terase montiran lift. U potkrovnom dijelu, s ulične strane zgrade, smještene su prostorije tekstilnih čuvaonica u koje se ulazilo iz dvorane za povremene izložbe, smještene između preparatorske radionice za tekstil i lijevoga krila zgrade.

Nakon završetka građevinskih radova pristupilo se uređenju tekstilnih čuvaonica. Oprema za čuvaonice rađena je planski za svaku pojedinu zbirku i u suradnji s kustosom voditeljem zbirke. Prostor čuvaonica podijeljen je u osam jedinica koje su opremljene ugradbenim ormarima s nizom ladica dok su ispod kosine krova ugrađeni ormari s kliznim vratima. Unutar čuvaonica građa je odvojena prema sistematiziranim zbirkama te pohranjena prema vrsti materijala i vrsti predmeta.

4 Promjene u stalnom postavu izvršene su i 1946. godine kada je Marijana Gušić došla na mjesto ravnateljice Muzeja. Tom prilikom je u suradnji s muzejskim stručnjacima izradila novi koncept stalnoga postava.

5 Dio navedenoga prostora početkom je osamdesetih pripao Hrvatskoj gospodarskoj komori, dok je u preostalom dijelu prostora smještena čuvaonica oglavlja i Zbirke oružja i nakita. 
Čuvaonica Zbirke vunenih tkanja i ćilima ${ }^{6}$ smještena je uz preparatorsku radionicu za tekstil, u prostoriju koja je podijeljena u dvije etaže u kojima je građa grupirana prema regijama i pohranjena na police. Prostor za čuvaonicu gornjih odijevnih predmeta od sukna, krzna i kože također je smješten uz preparatorsku radionicu za tekstil. Opremljen je ugradbenim ormarima $u$ dvije razine u kojima je građa pohranjena na vješalicama. S druge strane dvorane za povremene izložbe izdvojen je dio za čuvaonicu predmeta vezanih uz običaje. U ormare sa staklenim vratima pohranjene su igračke, predmeti od slame i odljevi kruha, dok su pokladne maske obješene u ormaru i učvršćene posebnim držačima. Čuvaonica za manje drvene predmete odvojena je od ostale drvene građe u prostoru na trećem katu desnoga krila zgrade. ${ }^{7}$ Dio čuvaonice je visokim ormarom odijeljen od radnoga prostora kustosa. U ormaru su pohranjene pastirske čaše, vodiri, britvenici, kutije i sl., dok su nasuprot, u namjenski izrađenim ormarima pohranjene preslice (usp. Gjetvaj 1973a: 17).

Čuvaonica Zbirke oglavlja, nakita, oružja i muzičkih instrumenata smještena je uz dvoranu za predavanja u prizemlju zgrade, u prostoriji koja je adaptacijom podijeljena u dvije etaže. Zbirke nakita i oružja smještene su u ugrađeni trezor na donjoj etaži (Sl. 1.), dok su Zbirke oglavlja i muzičkih instrumenata smještene na gornjoj etaži. Za njihovu pohranu iskorišteni su postojeći ormari (Ibid.: 18).

Ilustrativna građa smještena je u čuvaonicu na prvom katu desnoga krila zgrade. Opremljena je metalnim policama unutar kojih su pohranjene slike na staklu i ulja na platnu folklorne tematike, fotokopije većih formata i ostala dokumentacijska građa. Zbirka izvaneuropskih kultura smještena je u prizemnom dijelu zgrade, u prostoriji koja je također podijeljena na dvije etaže. U donjoj etaži je radna prostorija, dok je čuvaonica smještena na gornjoj. Predmeti iz Zbirki pokućstva, gospodarstva, maketa i keramike pohranjeni su u podrumskim čuvaonicama. Predmeti izrađeni od drva grupirani su po zbirkama i pohranjeni na police izrađene od staroga drvenog inventara, dok je keramika grupirana geografski i pohranjena na novonabavljene police. Prilikom adaptacije preparatorska radionica za drvo, keramiku i ostale materijale smještena je u podrum.

Prostorije koje su se nalazile u južnom dvorišnom dijelu zgrade podijeljene su u dvije etaže čime su se dobila četiri kata u kojima su smještene radne prostorije. Uz biblioteku na prvom katu dobile su se po dvije uredske prostorije i sanitarni čvor na svakoj etaži, unutar kojih su smještene soba ravnatelja, tajništvo, računovodstvo, uredi kustosa i dokumentacija. U tom dijelu zgrade izgrađeno je novo stubište, koje povezuje prostorije od podruma do četvrtoga kata s izložbenom dvoranom te lift za osoblje muzeja i transport teških predmeta. U desnom krilu zgrade prošireno je staro stubište koje povezuje izložbeni prostor prvoga kata s dvoranom za povremene izložbe (usp. Gjetvaj 1973b: 21-22).

6 Danas čuvaonica Zbirke prekrivača i prostirki.

7 Danas čuvaonica Zbirke pisanica, Zbirke božićnih jaslica, Zbirke razglednica i čestitki, Zbirke glazbala, Zbirke glazbala Franje Ksavera Kuhača (pohrana), Zbirke šarenih tikvica i preslica iz Zbirke alata i pomagala za obradu tekstila. 


\section{GODINA - DOGRADNJA PETOGA KATA}

Nakon adaptacije, kojom je dograđen četvrti kat na kojem je izveden ravni krov, došlo je do prodora oborinskih voda te je zbog nemogućnosti trajne sanacije 1989. godine izrađen projekt dogradnje krova nad tim dijelom objekta. U projekt je uključena izgradnja dodatnih prostorija kojom se dobilo $288,86 \mathrm{~m}^{2}$ muzejskih čuvaonica i 102,30 $\mathrm{m}^{2}$ radnih prostorija te sanitarni čvor, strojarnica i spremište. Podizanjem zida na dvorišnoj strani zgrade i izradom krovne konstrukcije omogućen je nesmetani prolaz sredinom prostora i pohrana građe uz nosive zidove, čime je dobiven u potpunosti funkcionalan prostor za pohranu građe i za uredske prostorije (usp. Živković 1989: 2). Dogradnjom potkrovlja djelomično su rasterećene podrumske čuvaonice iz kojih je u prostor petoga kata izmještena Zbirka lončarstva (Sl. 2.), dio Zbirke pokućstva i kućnoga inventara te dio Zbirke tradicijskoga gospodarstva.

\section{RAZDOBLJE OD 1991. DO 1995. GODINE}

Početkom Domovinskoga rata građa iz stalnoga postava ponovno je evakuirana, ali unutar zgrade Muzeja. Lutke u kompletima nošnji iz stalnoga postava narodnih nošnji Hrvatske smještene su u čuvaonicu oglavlja, oružja i nakita. Građa iz stalnoga postava izvaneuropskih kultura i sva tekstilna građa iz čuvaonica spremljena je u sanduke i smještena u prostor stalnoga postava osnovnih grana gospodarstva, dok su predmeti iz stalnoga postava osnovnih grana gospodarstva izmješteni u spremište u prizemlju desnoga krila zgrade. Nakon rata stalni postav na prvom katu je izložen prema prijašnjoj koncepciji dok je građa iz stalnoga postava osnovnih grana gospodarstva djelomično ostala u spremištu, a djelomično je pohranjena u čuvaonice te se taj prostor počeo koristiti za povremene izložbe.

\section{DODJELA POMOĆNE ZGRADE U KAČIĆEVOJ 9/2 2015. GODINE}

Konstantan rast muzejskoga fundusa ponovno je ukazao na nedostatak prostora za pohranu građe i loše stanje muzejskih čuvaonica ${ }^{8}$ što je bio temelj za traženje pomoćne zgrade za muzejske čuvaonice. Osnivač, grad Zagreb, 2015. godine je Muzeju dodijelio zgradu u Kačićevoj 9/2 za koju je 2017. godine izrađeno "Idejno rješenje za ishođenje posebnih uvjeta za rekonstrukciju zgrade Etnografskog muzeja u Zagrebu na lokaciji Kačićeva 9/2." Rekonstrukcijom zgrade ${ }^{9}$ osigurali bi se prostori za pohranu muzejske

8 U studenom 2017. godine u Muzeju je održana radionica RE-ORG (de Guichen i Matković 2017: 105 - 114) kojom su reorganizirane čuvaonice u podrumu i potkrovlju (5. kat) zgrade. Građa u navedenim čuvaonicama pohranjena je po zbirkama, ali su se prostorije čuvaonica i koridori, zbog nedostatka spremišnoga prostora koristile za odlaganje ambalaže, pratećih građevnih elemenata s održanih izložbi i pohranu etnografske građe koja je nakon carinskih zapljena pohranjena u Muzeju. Uslijed nastale situacije, građu koja se koristila za izložbe, posudbe ili prilikom muzejske obrade, nije bilo moguće vratiti u određene čuvaonice. Realizacijom projekta RE-ORG čuvaonicama je vraćena njihova osnovna namjena pohrane muzejskoga fundusa.

9 Prostor zgrade podijeljen je u četiri etaže u kojima su predviđene prostorije: čuvaonica i etnoteka u podrumu zgrade; čuvaonica, restauratorsko-preparatorska radionica za drvo, keramiku, kamen i metal te prostor za izložbe, predavanja i radionice u prizemlju zgrade; čuvaonica i restauratorsko-preparatorska radionica za tekstil na prvom 
građe, restauratorsko-preparatorske radionice i urede administracije, a projektom je predviđena i komunikacija s publikom putem otvorenih i studijskih čuvaonica te specijaliziranih programa.

\section{IZMJEŠTANJE UGROŽENE GRAĐE IZ TEKSTILNIH ČUVAONICA 2016. GODINE}

Zbog višegodišnjega problema s prodiranjem oborinskih voda u tekstilne čuvaonice, koji je za vrijeme dugotrajnoga kišnog razdoblja tijekom 2015. i 2016. godine eskalirao, odlučeno je da se dio prostora za povremene izložbe na četvrtom katu prenamijeni u privremenu čuvaonicu za najugroženiju tekstilnu građu. Prostor izložbene dvorane djelomično je pregrađen te je u njega izmještena građa iz tekstilnih čuvaonica koja je bila pohranjena u ugradbenim ormarima smještenim ispod kosine krova, dok je pedagoška radionica, koja se nalazila u pretprostoru restauratorsko-preparatorske radionice, preseljena u preostali dio dvorane.

\section{RAZDOBLJE OD 2017. DO 2019. GODINE}

Krajem 2016. godine Gradski zavod za zaštitu spomenika kulture i prirode podržao je zahtjev za temeljitom sanacijom i obnovom pročelja i krova zgrade Muzeja te je neposredno prije početka radova, u travnju 2017. godine, bilo neophodno izmjestiti i ostalu građu iz čuvaonica na četvrtom katu kao i onu pohranjenu na petom katu. Tekstilna građa premještena je u lijevo krilo stalnoga postava, koji je zatvoren, ${ }^{10}$ dok je građa smještena na petom katu djelomično izmještena uoči početka radova na krovištu u siječnju 2019. godine. Za privremeni smještaj te građe pregrađen je dio izložbene dvorane u prizemlju desnoga krila zgrade.

Radovi obnove pročelja i izmjene krovišta na zgradi, koji će trajati do sredine kolovoza 2019. godine, uvelike utječu na odvijanje redovnoga stručnog rada i muzejskih programa. Izmještena građa s četvrtoga i petoga kata nedostupna je, a sav stručni rad, koji se obavlja u neprikladnim uvjetima nastoji se uskladiti s građevinskim radovima. Unatoč tomu realiziraju se svi izložbeni programi kao i pedagoški, koji su tek u nekoliko navrata nakratko odgođeni.

Završetkom radova na krovištu planirano je vraćanje građe $u$ čuvaonice na četvrtom i petom katu nakon čega će biti neophodno čišćenje cjelokupnoga fundusa zbog izloženosti građe česticama nečistoća uslijed navedenih građevinskih radova.

katu zgrade; uredski prostori, dvorana za sastanke, prostori arhiva te prostori strojarskih i elektroinstalacija u potkrovlju zgrade (usp. Vujica 2017: 35).

10 U lipnju 2018. godine Stručno vijeće Muzeja podržalo je ideju redukcije postojećega stalnog postava koji bi se smjestio u otvoreno desno krilo zgrade i zadržao koncept podjele na tri etnografske zone (panonska, dinarska i jadranska). Provedbu su koordinirale muzejsko savjetnice Vesna Zorić i Aida Brenko te restauratorica Mihaela Grčević. Izložene su ukupno 54 lutke u kompletima nošnji, a uz vitrine s izloženim platnenim posobljem, zbog interesa javnosti, u preostale vitrine dodani su predmeti iz Zbirke čipkarstva te je osmišljena vitrina Dječji svijet u koju su uz lutke u dječjim nošnjama smještene tradicijske igračke. 


\section{KONZERVATORSKO-PREPARATORSKA SLUŽBA}

U Etnografskom muzeju su od njegova osnutka zapošljavani djelatnici koji su se brinuli o muzejskoj građi. Preparatorske radove na tekstilnoj građi obavljale su djelatnice sa završenom stručnom školom, dok su preparatori za drvo bile uglavnom osobe vješte stolarskim radovima. Za razliku od tekstilne preparatorske radionice, koja do adaptacije zgrade 1972. godine nije imala svoj prostor, popravci drvenih predmeta obavljali su se u dobro opremljenoj stolarskoj radionici, smještenoj u prostoriji uz dvorište lijevoga krila zgrade. Radovi na tekstilnoj građi u najvećoj mjeri su se svodili na redovito čišćenje ili prozračivanje predmeta te njihovu pohranu uz korištenje naftalina, globola i pantakanola. ${ }^{11}$ Drveni predmeti redovito su se mokro čistili te su se nakon sušenja premazivali mješavinom petroleja, terpentina, benzina i firnajza $a^{12}$ (usp. Gjetvaj 1989: 70).

Povećanjem broja stručnoga muzejskog kadra kao i boljom organizacijom rada u Muzeju početkom 1960-ih formirali su se stručni odjeli unutar ustanove. Statutom Etnografskoga muzeja u Zagrebu od 14. studenoga 1966. godine uz Opće odredbe i Zadatke Muzeja uspostavljena je i Unutrašnja organizacija Muzeja kojom su konzervatorsko-preparatorske radionice uz fotolaboratorij, crtačke radionice i radionice za mulaže, ${ }^{13}$ makete i modele činile dio Zajedničkih tehničkih službi muzeja (Ibid.: 52).

Nakon adaptacije zgrade, kojom je preparatorska radionica za tekstil dobila radne prostorije i ponovnim otvaranjem Muzeja 1972. godine započelo je sistematsko uređenje tekstilnih čuvaonica kojim se sva građa, koja je za vrijeme adaptacije zgrade bila pohranjena u sanduke, raspoređuje u nove čuvaonice te započinje sustavno provođenje mjera preventivne konzervacije i pohrane.

Donošenjem novoga Pravilnika o sistematizaciji radnih mjesta 13. prosinca 1977. godine i na osnovi Statuta Etnografskoga muzeja Konzervatorsko-preparatorska služba postaje dio Stručno-znanstvenoga odjela.

U preparatorskoj radionici za drvo, metal i ostale materijale 1980-ih godina su zaposlena dva preparatora sa srednjom stručnom spremom i pomoćni preparator koji je obavljao fizičke poslove vezane uz rad preparatorske radionice, kao i sve neophodne poslove unutar Muzeja. Radionica je 1988. godine dobila nove prostore u podrumu Muzeja, a uređena je i opremljena tek 1995. godine. Danas su u njoj zaposlena dva restauratora i jedan preparator, koji uz poslove preventivne konzervacije i restauracije na predmetima iz zbirki za koje su zaduženi, u nedostatku tehničke službe, uvelike sudjeluju u tehničkim realizacijama muzejskih programa.

Radionica za tekstil je početkom 2000-ih godina u dva navrata opremljena novim namještajem dok se na godišnjoj bazi nabavlja oprema neophodna za preventivnu konzervaciju i restauraciju građe. Danas su u njoj zaposlene dvije restauratorice i tri više preparatorice od kojih je svaka zadužena za određene tekstilne zbirke (S1. 3. i 4.).

11 Kemijska sredstva koja su se koristila prilikom pohrane tekstilnih predmeta kao zaštita od nametnika.

12 Laneno ulje s ubrzivačima sušenja koje se koristi kao impregnacija za drvo i u slikarstvu.

13 Fr. moulage: lijevanje u kalup, oblikovanje. 
Uz tekstilnu građu radionica je zadužena i za zaštitu predmeta iz Zbirke suvenira, Zbirke dječjih igračaka i igara, Zbirke predmeta narodne medicine, Zbirke čestitki i razglednica, Zbirke predmeta vezanih uz običaje i vjerovanja, pohrane Perinić te muzejske dokumentacije.

Važan segment djelatnosti koju obavljaju radionice čini i tehnička realizacija izložbi u sklopu kojih se unutar Odjela odvijaju svi poslovi vezani za građu, od pripreme materijala za izlaganje (čišćenje, konzervacija i restauracija) do tehničke realizacije.

\section{PREVENTIVNA KONZERVACIJA I RESTAURACIJA}

Preventivne metode zaštite, koje podrazumijevaju pravilno označavanje predmeta, čišćenje i pohranu primjenjuju se pri ulasku predmeta u Muzej. Nakon što se predmetu dodijeli inventarni broj u radionici se prema potrebi on čisti suho, mokro te $u$ iznimnim situacijama kemijski ${ }^{14}$ (tekstilna građa). Ako je građa zaražena nametnicima, podvrgava se tretmanu zamrzavanja, ${ }^{15}$ a u slučaju kada su uz nametnike prisutne i plijesni te mikroorganizmi primjenjuje se tretman gama zrakama ${ }^{16}$ na Institutu Ruđer Bošković u Zagrebu. Zbog velike količine građe koja je podložna djelovanju nametnika preventivno se, na godišnjoj bazi, provodi i zamagljivanje čuvaonica. ${ }^{17}$ Nakon čišćenja, predmet se označava, oprema i pohranjuje u čuvaonici. Osim preventivne konzervacije novopridošlih predmeta djelatnici sustavno provode mjere preventivne konzervacije na građi iz zbirki za koje su zaduženi.

Veliki izazov kod provođenja mjera zaštite i pohrane čini građa podložna oštećivanju. Čine ju kvarljivi predmeti (pisanice), lako lomljivi premeti (izrađeni od sjemenki, slame, papira, perja) te predmeti izrađeni od više različitih materijala (drva, kože, krzna, runa) kao što su pokladne maske. Kod navedenih predmeta, uz kurativne metode zaštite (tretman zamrzavanjem i/ili tretman gama zrakama), najčešce se primjenjuje metoda suhoga čišćenja usisavanjem ili otprašivanje.

Veliki iskorak u konzervatorskim i restauratorskim zahvatima na građi radionica za tekstil je učinila 2000-ih godina konzultirajući se s Odjelom za tekstil i papir Hrvatsk-

14 Kemijsko čišćenje, uz preporuku Zavoda za tekstilnu kemiju i ekologiju Tekstilno-tehnološkoga fakulteta Sveučilišta u Zagrebu, provodi se u kemijskoj čistionici Lemia d.o.o. Čiste se gornji dijelovi odjeće izrađeni od čohe. Predmeti se čiste u otopalu perkloretilena uz dodatak sredstava za mašćenje dok se sušenje vrši u mašini za kemijsko čišćenje pri temperaturi od $55^{\circ} \mathrm{C}$. Nabavom 2017. godine stroja za kemijsko čišćenje na alternativna otapala marke Renzacci, uz upotrebu Total TDC2000 izoparafinskoga otapala za sustav čišćenja s ugljikovodikovim otapalima, omogućeno nam je čišćenje predmeta izrađenih od materijala s nepostojanim bojama. Kemijski se čiste isključivo predmeti koji su mehanički u dobrom stanju.

15 Prije postupka zamrzavanja s predmeta se usisavanjem uklanjaju nečistoće i otpala vlakna te tragovi nametnika, jajašaca i larve. Predmet se stavlja u ledenicu na 14 dana pri temperaturi od $-18{ }^{\circ} \mathrm{C}$. Kada se izvadi, ostavlja se na ravnoj površini jedan dan da se postupno temperira. Predmeti koje tretiramo zamravanjm ne smiju sadržavati vosak, staklo, sintetiku, lak, kosti i rogove (usp. Grčević 2012: 204).

16 Radijacijska dezinsekcija predmeta izrađenih od tekstilnih vlakana provodi se u uređaju za ozračivanje uz dozu od 2 kGy, ako je predmet zaražen nametnicima, ili uz nešto višu dozu u slučaju zaraženosti plijesnima ili mikroorganizmima (Grčević 2012: 204). 
oga restauratorskog zavoda ${ }^{18}$ i zapošljavanjem djelatnica s iskustvom rada u njemu. ${ }^{19}$ Danas se pri restauriranju građe poštuju načela reverzibilnosti zahvata, minimalnoga zadiranja u predmet, konzerviranja zatečenoga stanja na predmetu, adekvatne pohrane te dokumentiranja svih faza radova. Zahvati koji se izvode na pojedinim predmetima prethodno se planiraju s nadležnim kustosom, voditeljem određene zbirke, ovisno o stanju predmeta i njegovoj budućoj namjeni.

Vođenje dokumentacije o obavljenim poslovima unutar Odjela obavezan je dio poslova u sklopu zaštite muzejskoga fundusa. Mjesečno se pišu izvješća o obavljenoj preventivnoj zaštiti, konzerviranju i restauriranju, dok se nakon opsežnih konzervatorsko-restauratorskih zahvata piše izvješće uz koje se prilažu fotografije svih faza radova. Od 2012. godine uveden je računalni program za vođenje sekundarne dokumentacije ( ++ ). Evidencijom postupaka $\mathrm{u}$ fondu Konzervatorsko-restauratorski postupci o obavljenoj preventivnoj konzervaciji i restauraciji izvješća se povezuju sa zapisom obrađenih muzejskih predmeta u računalnom programu za vođenje primarne dokumentacije $(\mathrm{M}++)$.

\section{ZAKLJUČAK}

Prikazom promjena smještaja stalnoga postava i dogradnji čuvaonica i radnih prostorija te prikazom djelovanja konzervatorsko-preparatorske službe od osnutka Muzeja do danas željelo se ukazati na cijeli niz problema koji su nastajali konstantnim rastom fundusa i broja djelatnika kroz stogodišnje postojanje Muzeja.

U nedostatku prostora neophodnih za obavljanje svih muzejskih djelatnosti (pohrane, preventivne konzervacije i restauracije građe, stručne i znanstvene obrade građe, prezentacije građe i pedagoških aktivnosti) adaptacijom zgrade i dogradnjom petoga kata, kojom su prostori prenamijenjeni i dograđivani, na kraći period se riješio problem manjka prostora u zgradi Muzeja.

Četrdeset sedam godina nakon posljednje adaptacije Muzej se našao na svojevrsnom početku. Zastarjelost stalnoga postava, neadekvatni i nedostatni prostori čuvaonica i radnih prostorija već duži niz godina otežavaju provođenje suvremene muzejske prakse. Projektom "Obnovljena baština za održivi i pametan razvoj u hiperpovezanom svijetu" iz 2016. godine planira se obnova unutrašnjosti zgrade i izrada novoga stalnog postava dok se za čuvaonice, restauratorsko-preparatorske radionice i urede administracije planira preseljenje u rekonstruirani prostor pomoćne zgrade dodijeljene Muzeju.

18 Potrebno je naglasiti dugogodišnju suradnju s Odjelom za tekstil, papir i kožu Hrvatskoga restauratorskog zavoda koji je slanjem kolega na specijalizaciju u muzeje u Velikoj Britaniji spoznaje o načinima kako predmete konzervirati i restaurirati prenio i Etnografskom muzeju u Zagrebu.

19 Marijana Najjar u Muzeju je zaposlena 2000. godine nakon godinu dana rada na Odjelu za tekstil, papir i kožu Hrvatskoga restauratorskog zavoda, dok je Mihaela Grčević zaposlena u Muzeju 2009. godine nakon deset godina rada na Odjelu za tekstil, papir i kožu Hrvatskoga restauratorskog zavoda. Zapošljavanjem djelatnika na radno mjesto restauratora 2009. u preparatorskoj radionici za tekstil i 2010. u preparatorskoj radionici za drvo, keramiku i ostale materijale mijenja se i naziv radionica u restauratorsko-preparatorska radionica za tekstil i restauratorskopreparatorska radionica za drvo, keramiku, kamen i metal. 
Preseljenjem čuvaonica i restauratorsko-preparatorskih radionica u nove prostore ne bi bilo omogućeno širenje zbirki na duže razdoblje, ali bi se osigurali adekvatni mikroklimatski uvjeti za opstojnost zbirki dok bi veće i dobro opremljene radionice omogućile nesmetano obavljanje poslova preventivne konzervacije i restauracije građe.

\section{LITERATURA I IZVORI:}

DE GUICHEN, Gaël i Ana MATKOVIĆ. 2017. "Kako san može postati stvarnost? Izvještaj o provedenom RE-ORG projektu u Etnografskom muzeju u Zagrebu”. Etnološka istraživanja 22: $105-112$.

ECKHEL, Nerina. 1999. 80 godina Etnografskog muzeja. Zagreb: Etnografski muzej.

GJETVAJ, Nada. 1973a. "Uređenje muzejskih depoa". Vijesti muzealaca i konzervatora Hrvatske 5: 17-19.

GJETVAJ, Nada. 1973b. "Historijat i adaptacija zgrade Etnografskog muzeja u Zagrebu". Vijesti muzealaca i konzervatora Hrvatske 5: 20-24.

GJETVAJ, Nada. 1989. “Etnografski muzej u Zagrebu - u povodu 70. obljetnice”. Etnološka istraživanja 5.

GRČEVIĆ, Mihaela. 2012. "Restauratorsko-preparatorska radionica za tekstil. Od preventivne zaštite do konzervatorsko-restauratorskog zahvata". Etnološka istraživanja 17: 203-240.

RADAUŠ RIBARIĆ, Jelka. 1973. "Značenje i zadaci obnovljenog Etnografskog muzeja u Zagrebu". Vijesti muzelaca i konzervatora Hrvatske 5: 5-9.

VUJICA, Kristina. 2017. Idejno rješenje za ishođenje posebnih uvjeta za rekonstrukciju zgrade Etnografskog muzeja u Zagrebu na lokaciji Kačićeva 9/2. Arhiv EMZ.

ŽIVKOVIĆ, Zdravko. 1989. Idejni projekt krova nad dijelom objekta s postojećim ravnim krovom. Arhiv EMZ. 